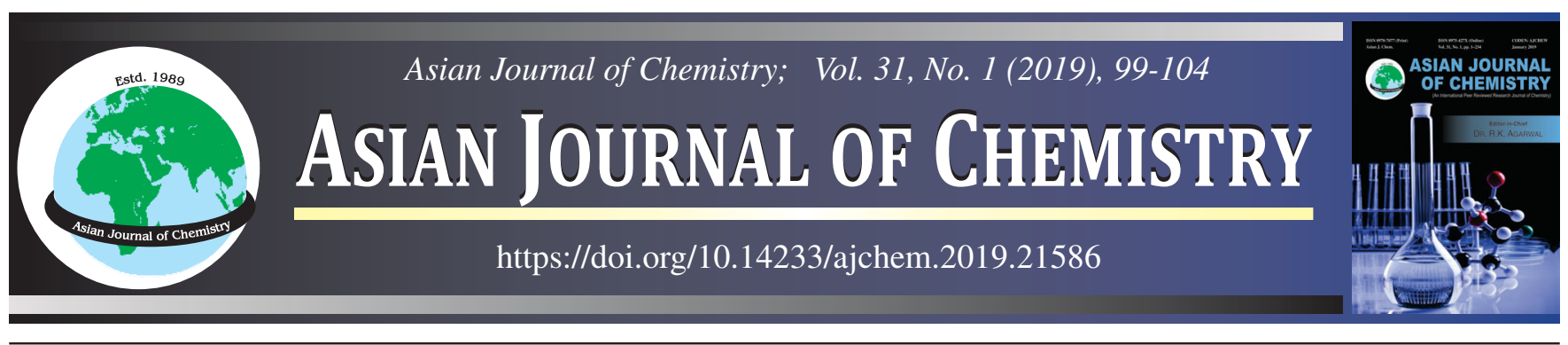

\title{
Synthesis, Characterization and Antibacterial Activity of Binuclear Chromium(II) Complexes of New Schiff Base Ligand Derived from Amino Acids
}

Voguri Haranath Babu ${ }^{1}$, Anna Venkateswara RaO ${ }^{1}$ and Ashok More ${ }^{2, *}$

${ }^{1}$ Department of Chemistry, Koneru Lakshmaiah Education Foundation, Green Fields, Vaddeswaram-522502, India

${ }^{2}$ Department of Chemistry, A.V.N. Engineering and Technology College, Ibrahimpatnam-501510, India

*Corresponding author: E-mail: ashokemore@gmail.com

Received: 16 July 2018;

Accepted: 18 August 2018;

Published online: 30 November 2018;

AJC-19165

Eight chromium(II) complexes of type, $\left[\mathrm{Cr}(\mathrm{L})\left(\mathrm{H}_{2} \mathrm{O}\right) \mathrm{x}\right] \cdot x \mathrm{H}_{2} \mathrm{O}$ (where $\mathrm{L}=$ Schiff base ligand) have been synthesized and characterized on the basis of elemental analysis IR, ${ }^{1} \mathrm{H},{ }^{13} \mathrm{C}$ NMR, mass and electronic spectroscopy, magnetic and conductance measurements. The amino acid schiff base ligand behaved as a octadentate ligand. The probable structures of the chromium(II) complexes have been elucidated and also the chromium(II) complexes were screened for antibacterial activity, which showed a moderate to good activity against Gram-positive and Gram-negative bacteria.

Keywords: Phthalaldehyde, Amino acid Schiff bases, Chromium(II) compounds, antibacterial Activity.

ᄂ $-\ldots-\ldots-\ldots-\ldots-\ldots-\ldots-\ldots-\ldots-\ldots-\ldots$

\section{INTRODUCTION}

$o$-Phthaladehyde (OPA) is used for the synthesis of acyclic, macrocyclic and other condensation products. Reactions of $o$-phthaladehyde with nucleophiles were extensively reviewed [1] and the Schiff bases have many variety of industrial and biological applications [2,3] such as photosynthesis and transport of oxygen in mammalian and other respiratory systems, $[4,5]$. On the other hand, transition metal complexes with a wide variety of Schiff bases having donor atoms such as nitrogen and oxygen around the metal ion have been used as catalyst for various organic transformations $[6,7]$. The metal complexes of $\alpha$-amino acids, amide group containing ligands are of great interest because they may be used as a basis for understanding metal-protein interaction [8]. If $\alpha$-amino acid is an acetyl or benzyl group than this can serves as a model of peptide a peptide bond $[9,10]$. Therefore, the study of coordination chemistry of these amino acids with metals can provide understanding the coordination chemistry for the protein at large. Many proteins within the body need metal ions and they are activated or deactivated by metal ions. These reversible effects are caused by ligation of the metal ions and protein. However, it is difficult to use the major techniques of structure elucidation on such large molecules as proteins. Study of amino acid complexation allows an examination, how substituent's on the amide nitrogen affects the coordination chemistry of the acids? Some groups have little effect on the amide nitrogen ability to coordinate to metal ions. These would includes the aromatic and aliphatic hydrocarbons as well as some alcohols [11].

Most of the articles dealing with the metal complexation of the amino acids use chromium as metal with salicylaldene gemiflaxacin which is derived from gemiflaxacin and salicylaldehyde has biological activity, the potency of uncoordinated ligand has enhanced on coordination with metal. The trend of the biological activity is more for coordination compounds such as, N-acetyl and N-benzoyl-glycine, L(+) alanine, L-valine, L-luecine and L-triptophan as ligands. Infrared spectroscopy was performed on the complexes and the results were compared with that of the alkali salts of amino acids $[8,9,12]$. Tetradentate Schiff bases composed of $\mathrm{N}_{2} \mathrm{O}_{2}$ donor atoms set have been recognized as a kind of important chelating ligands for designing medicinally and catalytically useful metal complexes $[13,14]$ and these are having flexible coordination behaviour, and also useful for the generation of dimeric and polymeric structures as synthones for supramolecular chemistry [15].

This is an open access journal, and articles are distributed under the terms of the Creative Commons Attribution-NonCommercial 4.0 International (CC BY-NC 4.0) License, which allows others to copy and redistribute the material in any medium or format, remix, transform, and build upon the material, as long as appropriate credit is given and the new creations are licensed under the identical terms. 


\section{EXPERIMENTAL}

The melting points of the ligand and chromium(II) complexes were obtained on the Buchi-510 melting point apparatus. The percentages of carbon, hydrogen, nitrogen in chromium complexes were determined at Technical University of Berlin, Berlin, Germany using a Perkin-Elmer CHN analyzer at $240^{\circ} \mathrm{C}$, UV-visible spectra were recorded with Shimadzu UV-160A, a UV-visible double beam spectrometer with matched quartz cells of path length $1 \mathrm{~cm}$ at National Institute of Technology Warangal, India. The IR spectra were recorded in $\mathrm{KBr}$ pellets on Perkin Elmer-283 spectrophotometer at the Central Instrumentation Centre, Kakatiya University, Warangal, India. The scanning rate was 6 min in the 4000-200 $\mathrm{cm}^{-1}$ range. A Jeol $100 \mathrm{MHz}$ FTNMR spectrometer was used for ${ }^{1} \mathrm{H}$ NMR spectra at the Indian Institute of Chemical Technology, Hyderabad, India. Brucker WH 270 (67.93 MHz) and Brucker WH 270 (109-29 MHz) spectrometers were used for ${ }^{13} \mathrm{C}$ NMR spectra. MICRO-MASS7070 spectrometer operating at $70 \mathrm{ev}$ using Gouy balance calibrated with $\mathrm{Hg}\left[\mathrm{Co}(\mathrm{NCS})_{4}\right]$ was used to determine magnetic susceptibilities of complexes in EtOH using Digisun digital conductivity meter model-909. The antibacterial activity of the compounds was determined by cup-plate method and the minimum inhibitory concentration by liquid dilution method.

All the analytical grade chemicals viz. chromium salts, ortho-pthalaldehyde, amino acids and other chemicals were purchased from Aldrich, USA. Eight new amino acid Schiff base ligands were synthesized as previously reported [2].

Preparation of ligand (L): To a boiling solution of 0.02 mol L(+) alanine (0.58 g), L-phenylalanine (3.72 g), L-lycine (3.72g), Methyldopa (4.22 g), sodium glutamate (3.38 g), Ltryptophan (4.8 g), L(+)-histidine (3.1g), glycyl-glycine (0.64 g) was dissolved in 10-30 mL of methanol slowly with constant stirring to an alcoholic solution $(20 \mathrm{~mL})$ containing $\mathrm{KOH}$. The solution was stirred for $1 \mathrm{~h}$ and then filtered. To the filtrate $o$-phthalaldehyde (1.32 g, $0.01 \mathrm{~mol})$ dissolved in $\mathrm{MeOH}(20$ $\mathrm{mL}$ ) was added dropwise with constant stirring and the resulting solution was evaporated under reduced pressure and kept at room temperature for $2 \mathrm{~h}$. The precipitate was washed with cold alcohol. The crystals were suction filtered and washed with diethyl ether and finally dried in vacuum (Scheme-I). The product was found to be TLC pure in methanol and chloroform mixture.
Synthesis of chromium complexes: To a boiling solution of chromium salt $(0.005 \mathrm{~mol})$ in methanol $(25 \mathrm{~mL})$ was added to a solution of the freshly prepared ligand $(0.005 \mathrm{~mol})$ in methanol $(30 \mathrm{~mL})$ with constant stirring. The reaction mixture was refluxed on a water bath for $2 \mathrm{~h}$ until a solid separated out. The solids were suction filtered, then purified by repeated washings with $\mathrm{CHCl}_{3}$ and finally with methanol after dried in vacuum over anhydrous calcium chloride (Scheme-I).

\section{RESULTS AND DISCUSSION}

The synthesis of new $\mathrm{Cr}$ (II) complexes involves the separate reactions with eight active amino Schiff base ligands. The percentage of carbon, hydrogen and nitrogen were determined by using $\mathrm{CHN}$ analyzer. The percentage of chromium in complexes was determined by the method described elsewhere [16]. The physical and analytical data (Table-1) are in good agreement with the proposed molecular formulae viz. $\left[\mathrm{Cr}_{2}(\mathrm{~L})\left(\mathrm{H}_{2} \mathrm{O}\right)_{\mathrm{x}}\right]$ $\cdot x \mathrm{H}_{2} \mathrm{O}$.

Infrared analysis: In order to study the binding modes of amino Schiff base ligands to chromium in the complexes, the infrared spectra of free ligands were compared with the spectra of new Schiff base Cr(II) complexes. A medium intensity of $v(C=N)$ band was observed [17] in the range of $1630-1608 \mathrm{~cm}^{-1}$. This band was observed to lower side about $10-30 \mathrm{~cm}^{-1}$ compared to the ligand spectra indicating the coordination of Schiff base nitrogen to the metal centre. These $\mathrm{Cr}$ (II) complexes showed broad band between $3592-3432 \mathrm{~cm}^{-1}$ which indicates the presence of lattice or coordinated water in these complexes. The presence of a medium sharp band in these complexes of $\mathrm{Cr}$ (II) in the region $762-712 \mathrm{~cm}^{-1}$ indicates the presence of coordinated water in all these complexes. The disappearance of a characteristic band of $v(\mathrm{COOH})$ of amino acid at $1722 \mathrm{~cm}^{-1}$ which is present in all the ligands and the appearance of two new absorption bands around 1592-1526, $1398-1342 \mathrm{~cm}^{-1}$ corresponding to $v_{\text {asy }}\left(\mathrm{COO}^{-}\right)$and $v_{\text {sym }}\left(\mathrm{COO}^{-}\right)$ in all complexes supports the participation of carboxylate oxygen of this group in the chelation. In the IR spectra of $\mathrm{Cr}$ (II) complex of CEIMPA (Fig. 1), the bands due to $v(\mathrm{~N}-\mathrm{H})$ of indole ring was not changed and indicated the non-coordination of indole ring nitrogen atoms to the metal ions in this complex on the other hand, the complex $\mathrm{Cr}$ (II) with CMAIPA, the obser-

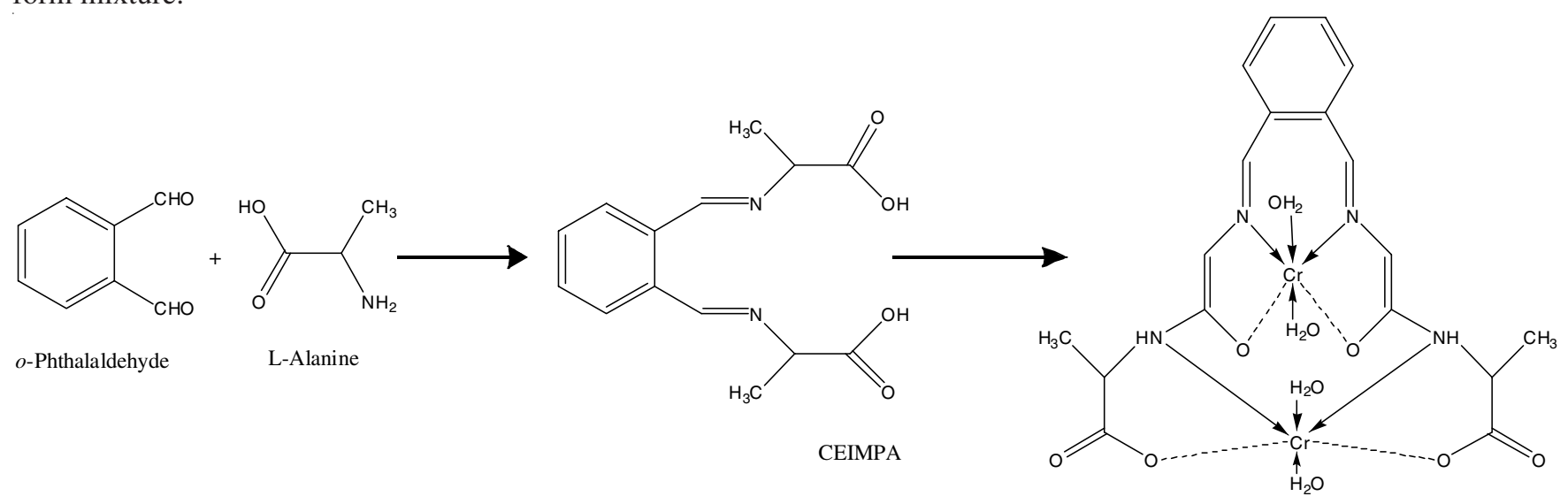

$\left[\mathrm{Cr}_{2}(\right.$ CEIMPA $\left.)\left(\mathrm{H}_{2} \mathrm{O}\right)_{2}\right] 2 \mathrm{H}_{2} \mathrm{O}$

Scheme-I: Synthesis of chromium(II) complex 
TABLE-1

PHYSICAL AND ANALYTICAL DATA OF Cr(II) COMPLEXES WITH AMINO SCHIFF BASE LIGANDS

\begin{tabular}{|c|c|c|c|c|c|c|c|c|}
\hline \multirow{2}{*}{$\begin{array}{l}\text { Complex } \\
\text { No. }\end{array}$} & \multirow{2}{*}{$\mathrm{Cr}$ (II) complex/Formula } & \multirow{2}{*}{$\begin{array}{l}\text { m.p. } \\
\left({ }^{\circ} \mathrm{C}\right)\end{array}$} & \multirow{2}{*}{ Color } & \multirow{2}{*}{ Yield (g) } & \multicolumn{4}{|c|}{ Elemental analysis (\%): Found (calcd.) } \\
\hline & & & & & $\mathrm{C}$ & $\mathrm{H}$ & $\mathrm{N}$ & $\mathrm{Cr}$ \\
\hline 1 & $\begin{array}{l}{\left[\mathrm{Cr}(\mathrm{CEIMPA})\left(\mathrm{H}_{2} \mathrm{O}\right)_{2}\right] \cdot 2 \mathrm{H}_{2} \mathrm{O}} \\
\mathrm{C}_{14} \mathrm{H}_{24} \mathrm{~N}_{2} \mathrm{O}_{8} \mathrm{Cr}\end{array}$ & 240 & Greenish & $1.33(73 \%)$ & $\begin{array}{c}42.00 \\
(42.01)\end{array}$ & $\begin{array}{c}6.04 \\
(6.02)\end{array}$ & $\begin{array}{c}7.00 \\
(7.05)\end{array}$ & $\begin{array}{r}12.99 \\
(12.95)\end{array}$ \\
\hline 2 & $\begin{array}{l}{\left[\mathrm{Cr}(\mathrm{CPEIAP})\left(\mathrm{H}_{2} \mathrm{O}\right)_{2}\right] \cdot \mathrm{H}_{2} \mathrm{O}} \\
\mathrm{C}_{27} \mathrm{H}_{33} \mathrm{~N}_{2} \mathrm{O}_{7} \mathrm{Cr}\end{array}$ & 238 & Dark green & $1.33(77.4 \%)$ & $\begin{array}{c}59.01 \\
(59.03)\end{array}$ & $\begin{array}{c}6.05 \\
(6.01)\end{array}$ & $\begin{array}{c}5.10 \\
(5.12)\end{array}$ & $\begin{array}{c}9.46 \\
(9.44)\end{array}$ \\
\hline 3 & $\begin{array}{l}{\left[\mathrm{Cr}(\mathrm{CPEIMP})\left(\mathrm{H}_{2} \mathrm{O}\right)_{2}\right] \cdot \mathrm{H}_{2} \mathrm{O}} \\
\mathrm{C}_{26} \mathrm{H}_{32} \mathrm{~N}_{4} \mathrm{O}_{7} \mathrm{Cr}\end{array}$ & 228 & Pale green & $1.33(78.5 \%)$ & $\begin{array}{c}55.31 \\
(55.20)\end{array}$ & $\begin{array}{c}5.71 \\
(5.69)\end{array}$ & $\begin{array}{c}9.92 \\
(9.90)\end{array}$ & $\begin{array}{c}9.21 \\
(9.20)\end{array}$ \\
\hline 4 & $\begin{array}{l}{\left[\mathrm{Cr}(\mathrm{CPMIMP})\left(\mathrm{H}_{2} \mathrm{O}\right) 2\right] \cdot \mathrm{H} 2 \mathrm{O}} \\
\mathrm{C}_{28} \mathrm{H}_{34} \mathrm{~N}_{2} \mathrm{O}_{11} \mathrm{Cr}\end{array}$ & 252 & Ash color & $1.34(80 \%)$ & $\begin{array}{c}53.67 \\
(53.63)\end{array}$ & $\begin{array}{c}5.47 \\
(5.43)\end{array}$ & $\begin{array}{c}4.47 \\
(4.45)\end{array}$ & $\begin{array}{c}8.30 \\
(8.32)\end{array}$ \\
\hline 5 & $\begin{array}{l}{\left[\mathrm{Cr}(\text { DCPIMP })\left(\mathrm{H}_{2} \mathrm{O}\right)_{2}\right] \cdot 2 \mathrm{H}_{2} \mathrm{O}} \\
\mathrm{C}_{18} \mathrm{H}_{28} \mathrm{~N}_{2} \mathrm{O}_{12} \mathrm{Cr}\end{array}$ & 342 & Brown color & $1.33(80.8 \%)$ & $\begin{array}{l}41.86 \\
(41.81)\end{array}$ & $\begin{array}{c}5.47 \\
(5.42)\end{array}$ & $\begin{array}{c}5.42 \\
(5.40)\end{array}$ & $\begin{array}{l}10.07 \\
(10.02)\end{array}$ \\
\hline 6 & $\begin{array}{l}{\left[\mathrm{Cr}(\mathrm{CEIMAP})\left(\mathrm{H}_{2} \mathrm{O}\right)_{2}\right] \cdot 2 \mathrm{H}_{2} \mathrm{O}} \\
\mathrm{C}_{20} \mathrm{H}_{28} \mathrm{~N}_{6} \mathrm{O}_{8} \mathrm{Cr}\end{array}$ & 345 & Dark brown & $1.33(84 \%)$ & $\begin{array}{c}45.11 \\
(45.03)\end{array}$ & $\begin{array}{c}5.30 \\
(5.29)\end{array}$ & $\begin{array}{c}15.78 \\
(15.73)\end{array}$ & $\begin{array}{c}9.77 \\
(9.75)\end{array}$ \\
\hline 7 & $\begin{array}{l}{\left[\mathrm{Cr}(\mathrm{CIMPAP})\left(\mathrm{H}_{2} \mathrm{O}\right)_{2}\right] \cdot 2 \mathrm{H}_{2} \mathrm{O}} \\
\mathrm{C}_{30} \mathrm{H}_{38} \mathrm{~N}_{4} \mathrm{O}_{8} \mathrm{Cr}\end{array}$ & 338 & Dark green & $1.32(81 \%)$ & $\begin{array}{c}56.78 \\
(56.74)\end{array}$ & $\begin{array}{c}6.04 \\
(6.01)\end{array}$ & $\begin{array}{c}8.83 \\
(8.80)\end{array}$ & $\begin{array}{c}8.19 \\
(8.17)\end{array}$ \\
\hline 8 & $\begin{array}{l}{\left[\mathrm{Cr}_{2}(\mathrm{CMAIPA})\left(\mathrm{H}_{2} \mathrm{O}\right)_{4}\right] \cdot 3 \mathrm{H}_{2} \mathrm{O}} \\
\mathrm{C}_{16} \mathrm{H}_{32} \mathrm{~N}_{4} \mathrm{O}_{13} \mathrm{Cr}\end{array}$ & 250 & Pale green & $1.33(98 \%)$ & $\begin{array}{c}35.56 \\
(35.53)\end{array}$ & $\begin{array}{r}5.97 \\
(5.95) \\
\end{array}$ & $\begin{array}{c}10.37 \\
(10.32)\end{array}$ & $\begin{array}{c}9.62 \\
(9.60)\end{array}$ \\
\hline
\end{tabular}

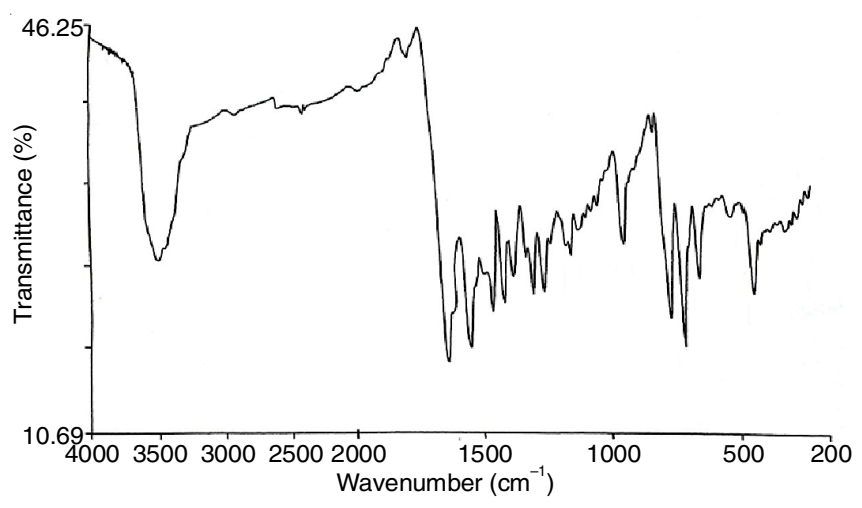

Fig. 1. IR spectrum of $\left[\mathrm{Cr}_{2}(\mathrm{CEIMPA})\left(\mathrm{H}_{2} \mathrm{O}\right)_{2}\right] \cdot 2 \mathrm{H}_{2} \mathrm{O}$

ved negative shift of $v(\mathrm{~N}-\mathrm{H})$ of glycyl glycine from 3320 to $3208 \mathrm{~cm}^{-1}$ describes that the coordination of amide nitrogen to $\mathrm{Cr}(\mathrm{II})[18]$. Besides this, the disappearance of $v(\mathrm{C}=\mathrm{O})$ of $\beta$-diketone part and the appearance of new band at $1568 \mathrm{~cm}^{-1}$ assignable to $\mathrm{v}(\mathrm{C}-\mathrm{O})$ which suggest that the carbonyl group involved in coordination in the enol form through deprotonation. Further, the metal ligand bond through carboxyl oxygen and imino nitrogen in all complexes [19] are confirmed by the far infrared spectra of the complexes showing non-ligand bands corresponding to $v(\mathrm{Cr}-\mathrm{O})$ vibrations at $470-450$ and $v(\mathrm{Cr}-\mathrm{N})$ vibrations at 544-508 $\mathrm{cm}^{-1}$ [20] (Table-2).

${ }^{1} \mathrm{H}$ NMR analysis: The ${ }^{1} \mathrm{H}$ NMR spectra of amine Schiff base lgands and with $\mathrm{Cr}(\mathrm{II})$ complexes are shown in Table-3. In free amine Schiff base spectra, the signals were appeared in the range of 8.22-8.24 ppm due to the presence of $\mathrm{HC}=\mathrm{N}$ protons $[21,22]$, however in the spectra of $\mathrm{Cr}$ (II) amino Schiff base complexes, the signals were appeared in the upfield region of 8.27-8.31 ppm, which indicates the coordination of imino nitrogen atom to $\mathrm{Cr}$ (II) [23] (Fig. 2). The ${ }^{1} \mathrm{H}$ NMR spectra of free amino Schiff base ligands have a characteristic signal for carboxylic group protons in the range of 10.15-10.90 ppm range and the disappearance of signal in ${ }^{1} \mathrm{H}$ NMR spectra of $\mathrm{Cr}$ (II) complexes indicates that the involvement of carboxylate ion oxygen in chelation through deprotonation. There is no specific change in the peak position corresponding to $\mathrm{NH}$ and aromatic protons.

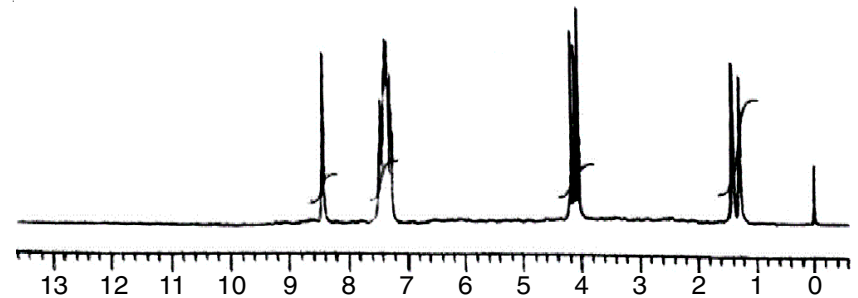

Fig. 2. ${ }^{1} \mathrm{HNMR}$ spectrum of $\left[\mathrm{Cr}_{2}(\mathrm{CEIMPA})\left(\mathrm{H}_{2} \mathrm{O}\right)_{2}\right] \cdot 2 \mathrm{H}_{2} \mathrm{O}$

${ }^{13} \mathrm{C}$ NMR analysis: ${ }^{13} \mathrm{C}$ NMR spectra of free amino Schiff base ligands and $\mathrm{Cr}$ (II) complexes were compared and the signals are found to have a consistent pattern. In the spectra of complexes, ${ }^{13} \mathrm{C}$ signals are observed in the downfield shift peak position regions of $\mathrm{CH}=\mathrm{N}$ group range is $170.2-174.5 \mathrm{ppm}$ [24]

TABLE-2

INFRARED SPECTRAL DATA OF Cr(II) COMPLEXES

\begin{tabular}{clcccccc}
\hline Complex No. & \multicolumn{1}{c}{$\mathrm{Cr}(\mathrm{II})$ complex } & $v(\mathrm{C}=\mathrm{N})$ & $v(\mathrm{NH} / * \mathrm{O}-\mathrm{H})$ & $\begin{array}{c}v(\mathrm{COO}-) \\
\text { asym/smy }\end{array}$ & $v\left(\mathrm{Cr}-\mathrm{H}_{2} \mathrm{O}\right)$ & $v(\mathrm{Cr}-\mathrm{N})$ & $v(\mathrm{Cr}-\mathrm{O})$ \\
\hline 1 & {$\left[\mathrm{Cr}(\mathrm{CEIMPA})\left(\mathrm{H}_{2} \mathrm{O}\right)_{2}\right] \cdot 2 \mathrm{H}_{2} \mathrm{O}$} & 1620 & 3430 & 1526,1342 & 748 & 544 \\
2 & {$\left[\mathrm{Cr}(\mathrm{CPEIAP})\left(\mathrm{H}_{2} \mathrm{O}\right)_{2}\right] \cdot \mathrm{H}_{2} \mathrm{O}$} & 1618 & 3432 & 1592,1370 & 762 & 450 \\
3 & {$\left[\mathrm{Cr}(\mathrm{CPEIMP})\left(\mathrm{H}_{2} \mathrm{O}\right)_{2}\right] \cdot \mathrm{H}_{2} \mathrm{O}$} & 1615 & 3590 & 1570,1380 & 754 & 542 & 458 \\
4 & {$\left[\mathrm{Cr}(\mathrm{CPMIMP})\left(\mathrm{H}_{2} \mathrm{O}\right)_{2}\right] \cdot \mathrm{H}_{2} \mathrm{O}$} & 1608 & 3428 & 1582,1396 & 758 & 530 & 452 \\
5 & {$\left[\mathrm{Cr}(\right.$ DCPIMP $\left.)\left(\mathrm{H}_{2} \mathrm{O}\right)_{2}\right] \cdot 2 \mathrm{H}_{2} \mathrm{O}$} & 1609 & 3432 & 1584,1355 & 728 & 508 & 452 \\
6 & {$\left[\mathrm{Cr}(\mathrm{CEIMAP})\left(\mathrm{H}_{2} \mathrm{O}\right)_{2}\right] \cdot 2 \mathrm{H}_{2} \mathrm{O}$} & 1614 & $3198^{*}$ & 1586,1363 & 710 & 522 & 460 \\
7 & {$\left[\mathrm{Cr}(\mathrm{CIMPAP})\left(\mathrm{H}_{2} \mathrm{O}\right)_{2}\right] \cdot 2 \mathrm{H}_{2} \mathrm{O}$} & 1628 & 3592 & 1578,1378 & 712 & 538 & 456 \\
8 & {$\left[\mathrm{Cr}_{2}(\mathrm{CMAIPA})\left(\mathrm{H}_{2} \mathrm{O}\right)_{4}\right] \cdot 3 \mathrm{H}_{2} \mathrm{O}$} & 1630 & $3206^{*}$ & 1579,1342 & 727 & 512 & 470 \\
\hline
\end{tabular}




\begin{tabular}{|c|c|c|}
\hline \multicolumn{3}{|r|}{$\begin{array}{c}\text { TABLE-3 } \\
{ }^{1} \mathrm{H} \text { NMR SPECTRAL DATA }\end{array}$} \\
\hline Complex No. & $\mathrm{Cr}(\mathrm{II})$ complex & ${ }^{1} \mathrm{H}$ NMR peak position $\delta \mathrm{ppm}$ \\
\hline 1 & {$\left[\mathrm{Cr}(\mathrm{CEIMPA})\left(\mathrm{H}_{2} \mathrm{O}\right)_{2}\right] \cdot 2 \mathrm{H}_{2} \mathrm{O}$} & $8.34(2 \mathrm{H}, \mathrm{s}, \mathrm{CH}=\mathrm{N}), 7.20-7.68(4 \mathrm{H}, \mathrm{m}, \mathrm{Ar}-\mathrm{H}), 4.18(4 \mathrm{H}, \mathrm{q}, \mathrm{CH}), 1.26\left(6 \mathrm{H}, \mathrm{d}, \mathrm{CH}_{3}\right)$. \\
\hline 2 & {$\left[\mathrm{Cr}(\mathrm{CPEIAP})\left(\mathrm{H}_{2} \mathrm{O}\right)_{2}\right] \cdot \mathrm{H}_{2} \mathrm{O}$} & $8.38(2 \mathrm{H}, \mathrm{s}, \mathrm{CH}=\mathrm{N}), 7.00-8.00(14 \mathrm{H}, \mathrm{m}, \mathrm{Ar}-\mathrm{H}), 4.20\left(4 \mathrm{H}, \mathrm{d}, \mathrm{CH}_{2}\right), 2.84(2 \mathrm{H}, \mathrm{t}, \mathrm{CH})$. \\
\hline 3 & {$\left[\mathrm{Cr}(\mathrm{CPEIMP})\left(\mathrm{H}_{2} \mathrm{O}\right)_{2}\right] \cdot \mathrm{H}_{2} \mathrm{O}$} & $\begin{array}{l}8.30(2 \mathrm{H}, \mathrm{s}, \mathrm{CH}=\mathrm{N}), 6.10-7.60(12 \mathrm{H}, \mathrm{m}, \mathrm{Ar}-\mathrm{H}), 5.40(2 \mathrm{H}, \mathrm{s}, \mathrm{Ar}-\mathrm{OH}), 4.02(2 \mathrm{H}, \mathrm{t}, \mathrm{CH}) \\
3.20\left(4 \mathrm{H}, \mathrm{d}, \mathrm{CH}_{2}\right) .\end{array}$ \\
\hline 4 & {$\left[\mathrm{Cr}(\mathrm{CPMIMP})\left(\mathrm{H}_{2} \mathrm{O}\right)_{2}\right] \cdot \mathrm{H}_{2} \mathrm{O}$} & $\begin{array}{l}8.36(2 \mathrm{H}, \mathrm{s}, \mathrm{CH}=\mathrm{N}), 6.60-7.60(10 \mathrm{H}, \mathrm{m}, \mathrm{Ar}-\mathrm{H}), 5.38(4 \mathrm{H} . \mathrm{s}, \mathrm{Ar}-\mathrm{OH}), 4.09(2 \mathrm{H}, \mathrm{d}, \mathrm{CH}), \\
2.50-2.69(2 \mathrm{H}, \mathrm{q}, \mathrm{CH}), 1.72\left(6 \mathrm{H}, \mathrm{d}, \mathrm{CH}_{3}\right) .\end{array}$ \\
\hline 5 & {$\left[\mathrm{Cr}(\mathrm{DCPIMP})\left(\mathrm{H}_{2} \mathrm{O}\right)_{2}\right] \cdot 2 \mathrm{H}_{2} \mathrm{O}$} & $\begin{array}{l}10.60(2 \mathrm{H}, \mathrm{s}, \mathrm{COOH}), 8.32(2 \mathrm{H}, \mathrm{s}, \mathrm{CH}=\mathrm{N}), 7.35-7.52(4 \mathrm{H}, \mathrm{m}, \mathrm{Ar}-\mathrm{H}), 4.26(2 \mathrm{H}, \mathrm{t}, \mathrm{CH}), 3.0 \\
\left(4 \mathrm{H}, \mathrm{t}, \mathrm{CH}_{2}\right), 2.47-2.49\left(4 \mathrm{H}, \mathrm{q}, \mathrm{CH}_{2}\right) .\end{array}$ \\
\hline 6 & {$\left[\mathrm{Cr}(\mathrm{CEIMAP})\left(\mathrm{H}_{2} \mathrm{O}\right)_{2}\right] \cdot 2 \mathrm{H}_{2} \mathrm{O}$} & $\begin{array}{l}8.38(2 \mathrm{H}, \mathrm{s}, \mathrm{NH}) 2.28(2 \mathrm{H}, \mathrm{s}, \mathrm{CH}=\mathrm{N}), 7.35-7.58(12 \mathrm{H}, \mathrm{m}, \mathrm{Ar}-\mathrm{H}), 3.49-3.60(2 \mathrm{H}, \mathrm{d}, \mathrm{CH}) \\
2.18-2.20\left(4 \mathrm{H}, \mathrm{d}, \mathrm{CH}_{2}\right) .\end{array}$ \\
\hline 7 & {$\left[\mathrm{Cr}(\mathrm{CIMPAP})\left(\mathrm{H}_{2} \mathrm{O}\right)_{2}\right] \cdot 2 \mathrm{H}_{2} \mathrm{O}$} & $\begin{array}{l}12.20(2 \mathrm{H}, \mathrm{d}, \mathrm{NH}), 8.32(2 \mathrm{H}, \mathrm{s}, \mathrm{CH}=\mathrm{N}), 7.37-7.73(4 \mathrm{H}, \mathrm{m}, \mathrm{Ar}-\mathrm{H}), 6.98(4 \mathrm{H}, \mathrm{s}, \mathrm{CH}), 3.79 \\
(2 \mathrm{H}, \mathrm{t}, \mathrm{CH}), 3.18\left(4 \mathrm{H}, \mathrm{s}, \mathrm{CH}_{2}\right) .\end{array}$ \\
\hline 8 & {$\left[\mathrm{Cr}_{2}(\mathrm{CMAIPA})\left(\mathrm{H}_{2} \mathrm{O}\right)_{4}\right] \cdot 3 \mathrm{H}_{2} \mathrm{O}$} & $\begin{array}{l}8.36(2 \mathrm{H}, \mathrm{s}, \mathrm{CH}=\mathrm{N}), 7.22-7.54(4 \mathrm{H}, \mathrm{m}, \mathrm{Ar}-\mathrm{H}), 4.78\left(4 \mathrm{H}, \mathrm{s}, \mathrm{CH}_{2}\right), 3.85\left(4 \mathrm{H}, \mathrm{d}, \mathrm{CH}_{2}\right), 6.0 \\
(2 \mathrm{H}, \mathrm{s}, \mathrm{NH}) .\end{array}$ \\
\hline
\end{tabular}

and for carbonyl carbon $\mathrm{COO}^{-}$ions in the range is 188.6-193.0 ppm in the complex NMR spectra indicates that ligand coordinates through both nitrogen atom of $\mathrm{CH}=\mathrm{N}$ and the oxygen of $\mathrm{COO}^{-}$ion [25].

Mass analysis: The proposed molecular formula of $\mathrm{Cr}$ (II) complex was confirmed by the mass spectral analysis through comparing its formula weight with $\mathrm{m} / \mathrm{z}$ values. The mass spectra contain molecular ion peaks at $\mathrm{m} / \mathrm{z}\left(\mathbf{M}^{+}\right)$of 400.0 (complex 1), 549.1 (complex 2), 564.1 (complex 3), 626.1 (complex 4), 516.1 (complex 5), 532.1 (complex 6), 634.2 (complex 7), 540.1 (complex 8). These data are in good agreement with the respective molecular formulae.

Electronic analysis: The electronic spectra of $\mathrm{Cr}$ (II) complexes with ligands exhibited three $d$ - $d$ transition bands in the regions 1040-1092, 516-542 and 426-496 $\mathrm{nm}$ assigned to complex displays three spin allowed transitions at $25,125\left({ }^{4} \mathrm{~A}_{2 g}\right.$ $\left.\rightarrow{ }^{4} \mathrm{~T}_{1 \mathrm{~g}}(\mathrm{P})\right]\left(\mathrm{v}_{3}\right) ; 24,038\left[{ }^{4} \mathrm{~A}_{2 \mathrm{~g}} \rightarrow{ }^{4} \mathrm{~T}_{1 \mathrm{~g}}(\mathrm{~F})\right]\left(\mathrm{V}_{2}\right) ; 18.622\left[{ }^{4} \mathrm{~A}_{2 \mathrm{~g}} \rightarrow\right.$ $\left.{ }^{4} \mathrm{~T}_{2 \mathrm{~g}}(\mathrm{~F})\right]\left(v_{1}\right)$; respectively. This indicates the octahedral geometry for $\mathrm{Cr}$ (II) complexes. The octahedral geometry of $\mathrm{Cr}$ (II) complexes is further supported by $v_{2}$ to $v_{1}$ ratio lying in the range of 2.00-2.08. The electronic spectra of bimolecular $\mathrm{Cr}$ (II) complex with ligand exhibited the $d-d$ transition bands in the regions 622 and $661 \mathrm{~nm}$ assigned to ${ }^{4} \mathrm{~A}_{2 \mathrm{~g}} \rightarrow{ }^{4} \mathrm{~T}_{1 \mathrm{~g}}(\mathrm{~F})$ (new) and ${ }^{4} \mathrm{~A}_{\mathrm{lg}}(\mathrm{F}) \rightarrow{ }^{4} \mathrm{~T}_{\mathrm{lg}}(\mathrm{F})$ (new) transitions, respectively [25].

Magnetic and conductance measurements: The molar conductance values for $\mathrm{Cr}(\mathrm{II})$ complexes $\left(10^{-3} \mathrm{M}\right)$ were determined in dichloromethane. These values are found to be low $\left(11.5-190 \mathrm{ohm}^{-1} \mathrm{~cm}^{2} \mathrm{~mol}^{-1}\right)$ indicating the non-electrolytic nature of the complexes. The magnetic moments indicate that the complexes are of high spin type. At room temperature, magnetic moment of chromium(II) is $3.63 \mathrm{BM}$, close to the spin only value suggesting an octahedral geometry around chromium ion [26]. Based on analytical and spectral data, octahedral structures have been tentatively proposed for all these complexes (Fig. 3). The $\beta$-value for chromium is 0.542 indicates that the complex has appreciable covalent character. Its e.p.r. spectrum was recorded using a polycrystalline sample at room temperature and the g-value was calculated using the expression: $g=2.0023(1-4 \lambda /$ $10 \mathrm{Dq}$ ), where $\lambda$ is the spin orbit coupling constant of metal ion in the complex. The g-value of $\mathrm{Cr}$ (II) is found to be 2.1548 [27]. Based on the analytical and spectral data octahedral structures have been tentatively proposed for all the $\mathrm{Cr}$ (II) complexes.
Antibacterial activity: The antimicrobial activities of the ligands and their chromium(II) complexes have screened against four bacteria by cup-plate method [28]. Preliminary screening for all the compounds was performed at fixed concentrations of $2 \mathrm{mg} / \mathrm{mL}$. Each compound was found to be acting on two types of gram +ve (Bacillus subtilis (MTCC-619) and Staphylococcus aureus (MTCC-96)) and gram-ve bacteria (Esherichia coli (MTCC-722) and Klebsiella pneumonia (MTCC-109). Out of eight amino Schiff base ligands, only three ligands viz. CEIMAP, CIMPAP and CMAIPA were found to be very effective based on the obtained values of relative zone of inhibition [29]. It has also been observed in the antimicrobial screening studies of chromium complexes showed higher activity than the corresponding free ligands against the same microorganism under identical experimental conditions. It was concluded that the ligands with $\mathrm{N}$ and $\mathrm{O}$ donor systems might have inhibited enzyme production. Chelation reduces the polarity of central ion mainly because of the partial sharing of its positive charge with the donor groups and possible $\pi$-electron delocalization within the whole chelate ring; this chelation increases the lipophilic nature of the central atom which favours its permeation through lipid layers of cell membrane [30]. From the preliminary screening, $\mathrm{Cr}$ (II) compounds were found to be active against four different strains of bacteria and their rank order to be as follows: complex $\mathbf{8}>$ complex $\mathbf{7}>$ complex $\mathbf{6}>$ complex $\mathbf{1}=$ complex $\mathbf{2}=$ complex $\mathbf{5}>$ complex $\mathbf{4}>$ complex $\mathbf{3}$ for Bacillus subtilis; complex $\mathbf{7}>$ complex $\mathbf{8}>$ complex $\mathbf{6}>$ complex $\mathbf{5}>$ complex $\mathbf{3}=$ complex $\mathbf{4}>$ complex $2>$ complex 1 for Staphylococcus aureus; complex $7>$ complex $\mathbf{6}>$ complex $\mathbf{8}>$ complex $\mathbf{5}>$ complex $\mathbf{3}>$ complex $\mathbf{1}=$ complex $\mathbf{2}>$ complex $\mathbf{4}$ for Esherichia coli; and complex $\mathbf{6}=$ complex $\mathbf{7}>$ complex $\mathbf{8}>$ complex $\mathbf{3}>$ complex $\mathbf{1}>$ complex $\mathbf{4}>$ complex $\mathbf{5}>$ complex $\mathbf{2}$ for Klebsiella pneumonia (Table-4).

\section{Conclusion}

Chromium(II) complexes with amino Schiff base ligands were prepared and octahedral structures have been assigned to these complexes by analyzing elemental and spectral data. These complexes have shown moderate to good antibacterial activity. 


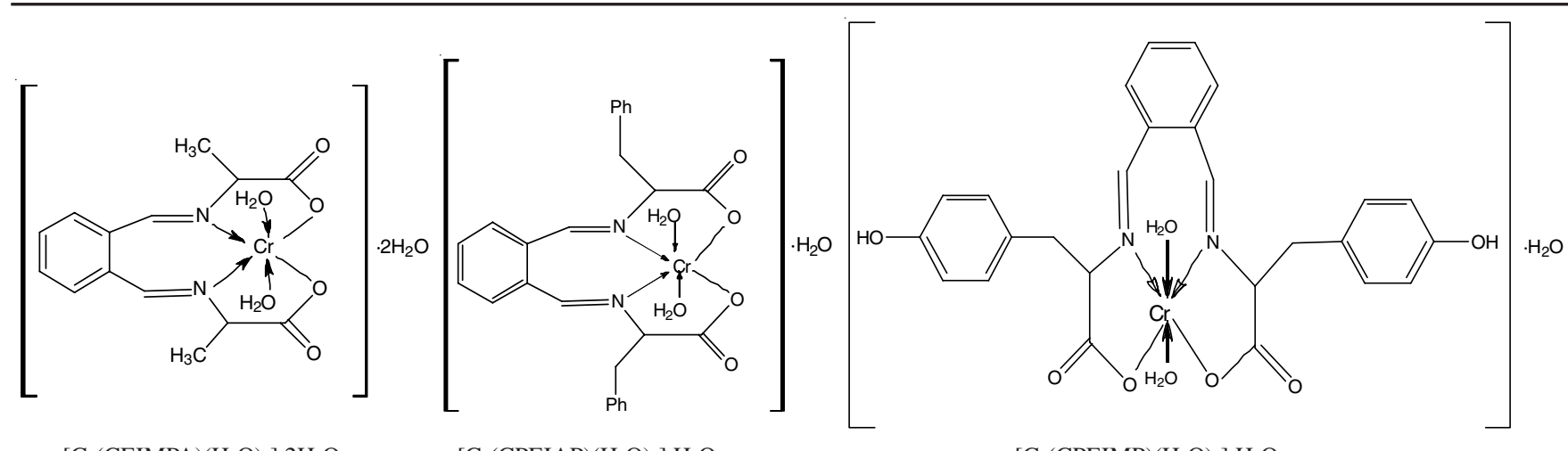

$\left[\mathrm{Cr}(\mathrm{CEIMPA})\left(\mathrm{H}_{2} \mathrm{O}\right)_{2}\right] \cdot 2 \mathrm{H}_{2} \mathrm{O}$

$\left[\mathrm{Cr}(\mathrm{CPEIAP})\left(\mathrm{H}_{2} \mathrm{O}\right)_{2}\right] \cdot \mathrm{H}_{2} \mathrm{O}$

$\left[\mathrm{Cr}(\mathrm{CPEIMP})\left(\mathrm{H}_{2} \mathrm{O}\right)_{2}\right] \cdot \mathrm{H}_{2} \mathrm{O}$

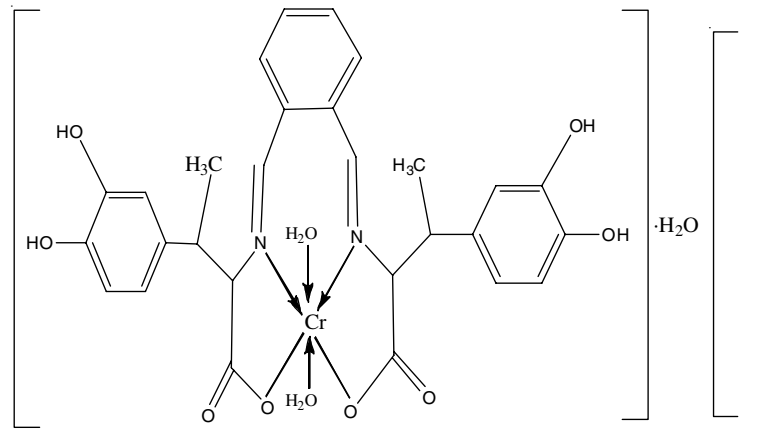

$\left[\mathrm{Cr}(\mathrm{CPMIMP})\left(\mathrm{H}_{2} \mathrm{O}\right)_{2}\right] \cdot \mathrm{H}_{2} \mathrm{O}$<smiles></smiles>

$\left[\mathrm{Cr}(\right.$ DCPIMP $\left.)\left(\mathrm{H}_{2} \mathrm{O}\right)_{2}\right] \cdot 2 \mathrm{H}_{2} \mathrm{O}$

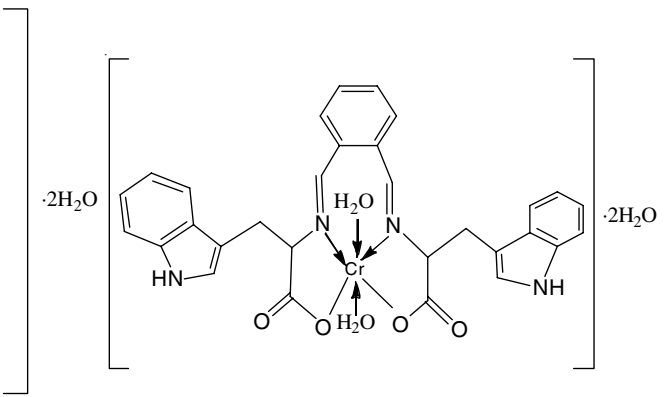

$\left[\mathrm{Cr}(\mathrm{CEIMAP})\left(\mathrm{H}_{2} \mathrm{O}\right)_{2}\right] \cdot 2 \mathrm{H}_{2} \mathrm{O}$

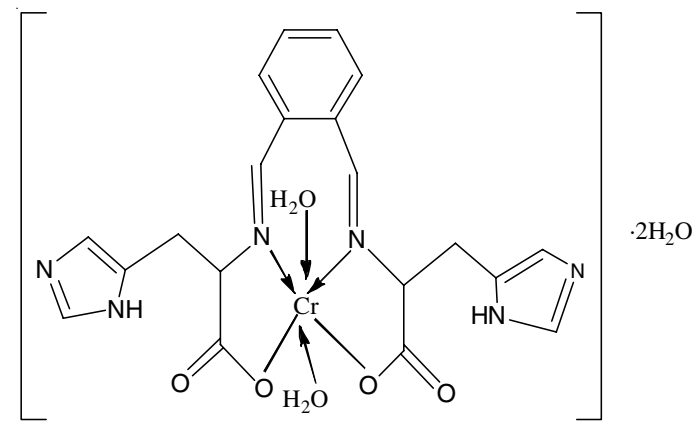

[Cr(CIMPAP) $\left.\left(\mathrm{H}_{2} \mathrm{O}\right)_{2}\right] \cdot 2 \mathrm{H}_{2} \mathrm{O}$

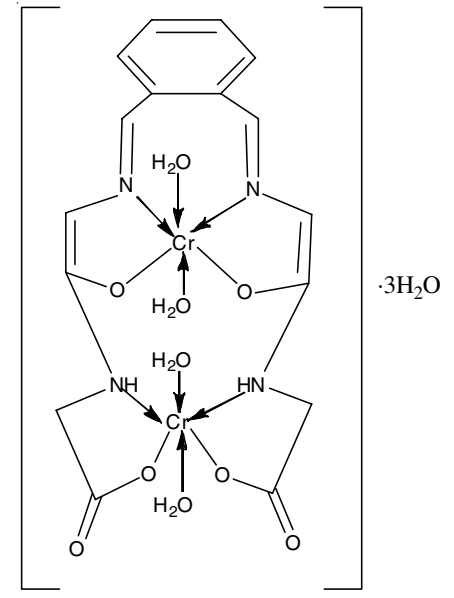

$\left[\mathrm{Cr}_{2}(\mathrm{CMAIPA})\left(\mathrm{H}_{2} \mathrm{O}\right)_{4}\right] \cdot 3 \mathrm{H}_{2} \mathrm{O}$

Fig. 3. Tentative structures of Schiff base complexes of chromium(II)

\begin{tabular}{|c|c|c|c|c|c|}
\hline \multicolumn{6}{|c|}{$\begin{array}{c}\text { TABLE-4 } \\
\text { ZONES OF INHIBITION FOR Cr(II) COMPLEXES WITH COORDINATED AMINE SCHIFF BASES AGAINST FOUR BACTERIA }\end{array}$} \\
\hline \multirow{2}{*}{$\begin{array}{c}\text { Complex } \\
\text { No. }\end{array}$} & \multirow{2}{*}{$\mathrm{Cr}(\mathrm{II})$ complex } & \multicolumn{4}{|c|}{ Zone of inhibition (mm) } \\
\hline & & Bacillus subtilis & Staphylococcus aureus & Esherichia coli & Klebsiella pneumonia \\
\hline 1 & {$\left[\mathrm{Cr}(\mathrm{CEIMPA})\left(\mathrm{H}_{2} \mathrm{O}\right)_{2}\right] \cdot 2 \mathrm{H}_{2} \mathrm{O}$} & 15 & 14 & 13 & 14 \\
\hline 2 & {$\left[\mathrm{Cr}(\mathrm{CPEIAP})\left(\mathrm{H}_{2} \mathrm{O}\right)_{2}\right] \cdot \mathrm{H}_{2} \mathrm{O}$} & 15 & 12 & 13 & 08 \\
\hline 3 & {$\left[\mathrm{Cr}(\mathrm{CPEIMP})\left(\mathrm{H}_{2} \mathrm{O}\right)_{2}\right] \cdot \mathrm{H}_{2} \mathrm{O}$} & 13 & 14 & 14 & 15 \\
\hline 4 & {$\left[\mathrm{Cr}(\mathrm{CPMIMP})\left(\mathrm{H}_{2} \mathrm{O}\right)_{2}\right] \cdot \mathrm{H}_{2} \mathrm{O}$} & 14 & 14 & 11 & 13 \\
\hline 5 & {$\left[\mathrm{Cr}(\mathrm{DCPIMP})\left(\mathrm{H}_{2} \mathrm{O}\right)_{2}\right] \cdot 2 \mathrm{H}_{2} \mathrm{O}$} & 15 & 16 & 16 & 11 \\
\hline 6 & {$\left[\mathrm{Cr}(\mathrm{CEIMAP})\left(\mathrm{H}_{2} \mathrm{O}\right)_{2}\right] \cdot 2 \mathrm{H}_{2} \mathrm{O}$} & 34 & 30 & 36 & 32 \\
\hline 7 & {$\left[\mathrm{Cr}(\mathrm{CIMPAP})\left(\mathrm{H}_{2} \mathrm{O}\right)_{2}\right] \cdot 2 \mathrm{H}_{2} \mathrm{O}$} & 34 & 33 & 37 & 32 \\
\hline 8 & {$\left[\mathrm{Cr}_{2}(\mathrm{CMAIPA})\left(\mathrm{H}_{2} \mathrm{O}\right)_{4}\right] \cdot 3 \mathrm{H}_{2} \mathrm{O}$} & 36 & 34 & 32 & 33 \\
\hline
\end{tabular}

\section{ACKNOWLEDGEMENTS}

The authors thank to President Koneru Sathyanarayana Garu, K L University, India for performing this work and also thanks to A. Pavanreddy Garu, Director, A.V.N. Institute of
Engineering and Technology, Hyderabad, India for supporting this extensive research work. Thanks are also due to Prof. Vadde Ravinder, Kakatiya University, Warangal, India for valuable suggestions during the course of this work. 


\section{CONFLICT OF INTEREST}

The authors declare that there is no conflict of interests regarding the publication of this article.

\section{REFERENCES}

1. P.G. Cozz, J. Chem. Soc. Rev., 33, 410 (2004); https://doi.org/10.1039/B307853C.

2. A.M. Abu-Dief and I.M.A. Mohamed, Beni-Suef Univ. J. Basic Appl. Sci., 4, 119 (2015);

https://doi.org/10.1016/j.bjbas.2015.05.004.

3. G. Kumar, D. Kumar, C.P. Singh, A. Kumar and V.B. Rana, J. Serbian Chem. Soc., 75, 629 (2010); https://doi.org/10.2298/JSC090704037K.

4. P.K. Coughlin and S.J. Lippard, J. Am. Chem. Soc., 106, 2328 (1984); https://doi.org/10.1021/ja00320a018.

5. L.Y. Lindoy, The Chemistry of Microcyclic Liquids, Cambridge University Press: Cambridge (1989).

6. T. Katsuki, Coord. Chem. Rev., 140, 189 (1995); https://doi.org/10.1016/0010-8545(94)01124-T.

7. E.G. Samsel, K. Srinivasan and K.J. Kochi, J. Am. Chem. Soc., 107, 7606 (1985); https://doi.org/10.1021/ja00311a064.

8. L. Antolini, L. Menabue, M. Saladini and P. Morini, Inorg. Chim. Acta, 46, L77 (1980); https://doi.org/10.1016/S0020-1693(00)84145-6.

9. L. Antolini, L. Menabue, P. Prampolini and M. Saladini, Inorg. Chim. Acta, 66, 19 (1982); https://doi.org/10.1016/S0020-1693(00)85784-9.

10. L.P. Battaglia, A.B. Corradi, G. Marcotrigiano, L. Menabue and G.C. Pellacani, Inorg. Chem., 20, 1075 (1981); https://doi.org/10.1021/ic50218a024.

11. G. Lusvardi, L. Menabue and M. Saladini, Inorg. Chim. Acta, 218, 53 (1994); https://doi.org/10.1016/0020-1693(93)03793-A.

12. L. Antolini, L.P. Battaglia, G.B. Gavioli, A.B. Corradi, G. Marcotrigiano, L. Menabue and G.C. Pellacani, J. Am. Chem. Soc., 105, 4327 (1983); https://doi.org/10.1021/ja00351a034.

13. M.K. Taylor, J. Reglinski and D. Wallace, Polyhedron, 23, 3201 (2004); https://doi.org/10.1016/j.poly.2004.10.002.
14. D. Sinha, A.K. Tiwari, S. Singh, G. Shukla, P. Mishra, H. Chandra and A.K. Mishra, Eur. J. Med. Chem., 43, 160 (2008); https://doi.org/10.1016/j.ejmech.2007.03.022.

15. M.Y. Khuhawar, M.A. Mughal and A.H. Channar, Eur. Polym. J., 40, 805 (2004); https://doi.org/10.1016/j.eurpolymj.2003.11.020.

16. G. Kesser, R.J. Meyer and R.P. Larsen, Anal. Chem., 38, 221 (1966); https://doi.org/10.1021/ac60234a019.

17. S.C. Cummings and D.H. Busch, J. Am. Chem. Soc., 92, 1924 (1970); https://doi.org/10.1021/ja00710a023.

18. S.A. Sallam, Transition Metal Chem., 31, 46 (2006); https://doi.org/10.1007/s11243-005-6312-4.

19. W. Zhong, W. Zishen, Y. Zhenhuan and H. Qinghua, Transition Met. Chem., 19, 235 (1994); https://doi.org/10.1007/BF00161897.

20. V. Kumar and R. Dhakarey, J. Indian Coun. Chem., 20, 46 (2003)

21. P. Muralidhar Reddy, Y.-P. Ho, K. Shanker, R. Rohini and V. Ravinder, Eur. J. Med. Chem., 44, 2621 (2009); https://doi.org/10.1016/j.ejmech.2008.09.035.

22. M.J. O’Donnell and R.L. Polt, J. Org. Chem., 47, 2663 (1982); https://doi.org/10.1021/jo00134a030.

23. K. Shanker, P.M. Reddy, R. Rohini, Y.P. Ho and V. Ravinder, J. Coord. Chem., 62, 3040 (2009) https://doi.org/10.1080/00958970902980511.

24. Z.H. Chohan and M. Praveen, Appl. Organomet. Chem., 15, 617 (2001); https://doi.org/10.1002/aoc.179.

25. A.B.P. Lever, Inorg. Electronic Spectroscopy, Elsevier: Amsterdam, edn 2 (1984)

26. B.N. Figgis, Introduction to Ligand Field Theory, Wiley: New York (1978)

27. S. Chandra and K. Gupta, Transition Met. Chem., 27, 196 (2002); https://doi.org/10.1023/A:1013935602736.

28. T.P.T. Cushnie and A.J. Lamb, Int. J. Antimicrob. Agents, 26, 343 (2005); https://doi.org/10.1016/j.ijantimicag.2005.09.002.

29. P.M. Reddy, A.V.S.S. Prasad and V. Ravinder, Transition Met. Chem., 32, 507 (2007); https://doi.org/10.1007/s11243-007-0205-7.

30. R. Maruvada, S.C. Pal and G. Balakrish Nair, J. Micro. Bio. Methods, 20, 115 (1994); https://doi.org/10.1016/0167-7012(94)90014-0. 